\title{
Identifying the components of ecological variation in a marine benthic megafauna
}

\author{
Ana Maria Setubal Pires-Vanin \\ Instituto Oceanográfico, Universidade de São Paulo \\ (Caixa Postal 66149, 05315-970 São Paulo, Brasil)
}

- Abstract: Current work in benthic ecology highlights the importance of the temporal component of ecological variation for distribution and abundance of organisms. However, this approach is limited by the difficulty in separating and measure the constituents of such variation. The present study aims to separate and identify the environmental and temporal components of ecological variation in the abundance of the benthic invertebrate community from the São Sebastião Channel, southeastern Brazil, by canonical correspondence analysis. The area is seasonally submitted to the intrusion of a cold and saline water mass, an important factor influencing benthic communities. The composition and abundance of the megafauna were investigated at five sites from November 1993 to August 1994. A total of 93 species were collected. Average density reached 187 individuals per catch with highest numbers in summer. A striking difference in species composition and abundance was observed in the catches through the year and the results suggested a different structure of the assemblages for each season. Four independent components of the species variation could be separated and identified: pure environmental, pure temporal, environmental with temporal structure and undetermined. The large amount of environmental variation is related to sandy bottoms and depth influence, whereas the time factor can be interpreted as both the seasonal intrusion of the South Atlantic Central Water and the biological cycles of some key-species.

- Resumo: Os estudos atuais em ecologia bêntica apontam para a importância do componente temporal da variação ecológica na distribuição e abundância dos organismos. Entretanto, a abordagem temporal é limitada pela dificuldade na separação e quantificação dos constituintes dessa variação. $O$ presente estudo visa separar e quantificar os componentes ambiental e temporal da variação ecológica na distribuição da megafauna bêntica no Canal de São Sebastião, sudeste brasileiro, através da análise de correspondência canônica. A área é submetida sazonalmente à intrusão de uma massa de água fria e salina, que influencia a distribuição e abundância das espécies. A composição e abundância do megabentos foi investigada em cinco locais dentro do Canal, no período compreendido entre novembro de 1993 e agosto de 1994. Foram obtidas 93 espécies, a densidade média foi de 187 indivíduos por arrasto e os valores máximos localizaram-se no verão. Observou-se uma notável diferença na composição e dominância específica durante o ano, e os resultados sugerem a existência de comunidades estruturadas diferentemente em cada época amostrada. Pôde-se separar e quantificar quatro componentes independentes da variação na abundância das espécies: ambiental puro, temporal puro, ambiental com estrutura temporal e indeterminado. Grande quantidade de variação ambiental está relacionada com a ocorrência de fundos arenosos e com o gradiente de profundidade, enquanto que o fator temporal pode ser interpretado como a intrusão sazonal da Água Central do Atlântico Sul aliada ao ciclo biológico de algumas espécies-chave do sistema.

- Descriptors: Species variation, Temporal variation, Megabenthos, Correspondence analysis.

- Descritores: Abundância específica, Variação temporal, Megabentos, Análise de correspondência. 


\section{Introduction}

The influence of spatial heterogeneity on the distribution of species and communities is well documented in the literature (Long et al., 1995; Maes et al., 1998). Besides spatial heterogeneity, temporal variation can also be an important factor structuring communities, and is mostly associated with other biological and environmental variables. Soto et al., (1999) reported that climatic condition and prevailing hydrographic regime may regulate both seasonal and annual variability of the decapod megafauna assemblages at the continental shelf from the southwest Gulf of Mexico.

The influence of spatial heterogeneity and temporal variation on the macrobenthic and megabenthic communities at the southern Brazilian shelf and slope has been studied since 1985 (PiresVanin, 1993; Sumida \& Pires-Vanin, 1997; ValérioBerardo et al., 2000). The fauna was found to be affected locally by a seasonal deep ocean water intrusion - the South Atlantic Central Water (SACW), which creates complicated hydrographic patterns and influences the marine organisms in a way which is still little understood. In spite of the conspicuous temporal influence observed, a quantitative approach to explain such variation was never attempted.

Even though the temporal components of ecological variation make the study of community structure highly complex, ecologists usually do not know the fraction of variation on the species data controlled only by environment or time, or by both sets of variables. In order to help solving this problem, Borcard et al. (1992) proposed a method of partialling out the spatial component of ecological variation based on canonical correspondence analysis (CCA) and redundancy analysis (RDA). The authors used constrained and partial canonical techniques (ter Braak, 1988) and separated the species abundance variation into four independent components: a pure spatial, a pure environmental, an environmental component with spatial structure and an undetermined component.

The São Sebastião Channel is a complex hydrological system placed at the northern São Paulo State shelf. Its abrupt narrowing in the middle and steep bottom topography influence the hydrodynamics of the area as well as the pattern of sedimentation. In addition to the seasonal intrusion of the South Atlantic Central Water (SACW), the Channel has a wind driven current flowing in opposite direction during summer and winter months (Leandro, 1999). These aspects make the area favorable to studies with temporal approach.

The present paper describes the seasonal variation in the abundance of the benthic megafauna from the São Sebastião Channel, and separates and identifies the four independent components of the variation by canonical correspondence analysis. This data-verification would make it possible to find responsible variables in monitoring community, and contribute to the understanding of the processes at work in the area.

\section{The study area}

The São Sebastião Channel is an area of nearly $98 \mathrm{~km}^{2}$ located between $23^{\circ} 41^{\prime} \mathrm{S}$ and $23^{\circ} 53.5^{\prime} \mathrm{S}$, and between $45^{\circ} 19^{\prime} \mathrm{W}$ and $45^{\circ} 30^{\prime} \mathrm{W}$ in the northern coast of São Paulo State, south Brazilian Bight (Fig. 1). It separates the large São Sebastião Island from the mainland and is oriented in SW-NE direction. It is nearly $24 \mathrm{~km}$ long and $5.8 \mathrm{~km}$ wide in the north end and $6.4 \mathrm{~km}$ in the south, narrowing middlewards to just about $2.0 \mathrm{~km}$. The axis of the channel is situated near the island, and greater depths are located both in the south and north entrances ( 25 and $20 \mathrm{~m}$ respectively), and in the middle $(45 \mathrm{~m}$ ) (Fig. 1). Very fine sand is deposited on the southern part of the channel, finer sediments (silt) in the axis and coarse sand along the island side (Furtado, 1995).

Concerning water circulation, the channel is protected from directed wave action from the open sea due to the presence of the São Sebastião Island. The main flow of the currents is parallel to the longitudinal axis of the channel, with predominant $\mathrm{NE}$ orientation. In summer, when the NE wind predominates, the direction of the current changes to south (Silva, 1995).

This part of the Brazilian shelf represents an oceanographic peculiarity: the intrusion of a cold and saline water mass, the South Atlantic Central Water (SACW), in summer, flowing near the bottom from the slope towards the coast. Therefore, a two-layer water stratification is established during this time with a conspicuous termocline at mid depths. The $\mathrm{SACW}$ is rich in nutrients and, when it reaches the euphotic zone, it eutrophicates the water enlarging the primary production of the area by one order of magnitude (Aidar et al., 1993). Besides, it changes the structure of the benthic communities (Pires, 1992; Santos \& Pires-Vanin, 1999).

\section{Material and methods}

\section{Sampling}

Sampling was carried out seasonally during one year at five places of the São Sebastião Channel, with the research boat "Veliger II" of the University of São Paulo (Fig. 1). The selected station sites were the only places where bottom trawling could be 
conducted. As the channel is route for petroleum tankers, many oil pipelines are laid over the bottom, difficulting the trawling operation in most parts. Samples were taken between 8 and $24 \mathrm{~m}$ depth, from November 1993 to August 1994. The benthic megafauna was collected with an otter trawl of $20-\mathrm{mm}$ mesh size and $6 \mathrm{~m}$ mouth width when expanded, and hauled during 15 minutes parallel to the coast at approximately the same depth. Two replications were made at each sampling place in the four seasons summing up 40 trawls. Each sample was numbered according to its original site ( 1 to 5) plus a letter indicating the season of the year. when it was obtained (e.g., IP = site 1, springtime; $1 \mathrm{~S}$ = site 1 , summer). Upon retrieval, invertebrates were frozen on board.

Temperature, salinity and bottom water oxygen concentration were measured and sediment was collected with a vanVeen grab for textural analysis, before trawling. Salinity was measured using a conductivity salinometer. The oxygen saturation level was calculated based on oxygen concentration data (Riley, 1971; UNESCO, 1973).

Grain size was determined through sieving and pipetting techniques (Suguio, 1973). The carbonate content of each sample was calculated by the weight difference prior to and after acidification (Gross, 1971). The organic carbon was measured by titration with potassium dichromate (Gaudette et al., 1974).

The organisms were identified to species level for most taxonomic groups (except for Porifera) and counted. The nomenclature of the penaeids decapods followed Pérez Farfante and Kensley (1997).

\section{Species, environment and time matrices}

In order to bring the database to a more workable size, the initial species data matrix (20 station-points $\mathrm{x} 93$ species) was reduced by eliminating species if less than 2 individuals per sampled period were collected (Jackson, 1972; Pires, 1992). The resulting matrix (20 stations $\times 24$ species) was analyzed after the $\log$ transformation of abundance data, $\mathrm{y}=\ln (\mathrm{x}+1)$ to avoid skewness (Cassie \& Michael, 1968).

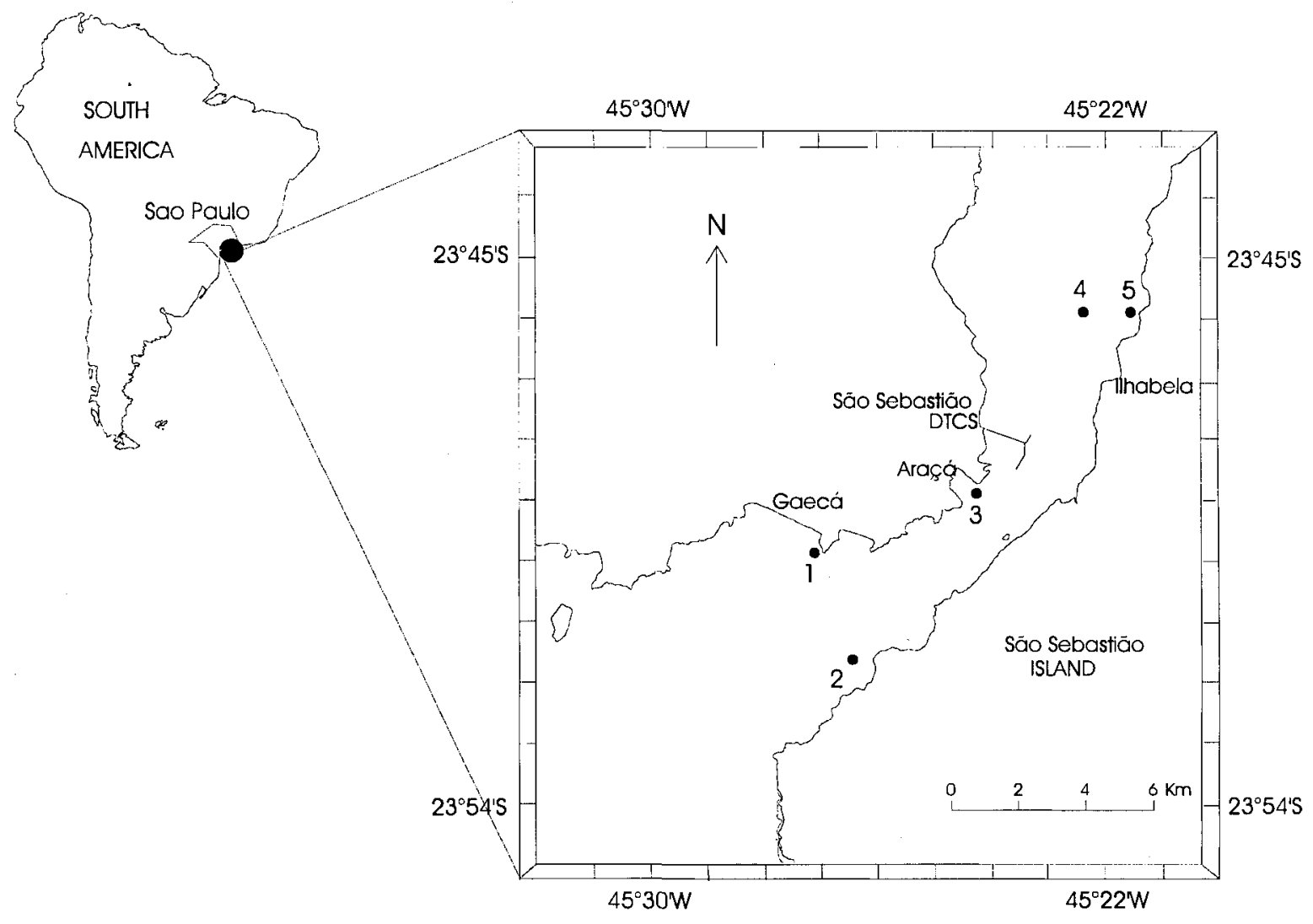

Fig. 1. Geographic location of the study area. Sampling sites are displayed as filled circles. 
The 13 quantitative environmental parameters measured were: depth, temperature, salinity, oxygen concentration (\%), biodetritic carbonate, organic carbon, coarse sand, medium sand, fine sand, very fine sand, silt, clay, and mean diameter of the sediment. Environmental variables data were standardized after the formula $Y=(X-$ $\left.X_{\text {med }}\right) / S_{x}$, where $Y=$ standardized variable, $X=$ nonstandardized variable, $X_{\text {med }}=X$ medium value and $S_{x}$ $=\mathrm{X}$ standard deviation. The resulting matrix $(20$ stations $\times 13$ variables) was employed to perform the correspondence analysis (CA). To minimize the number of variables with the maximum explanatory power each environmental variable was chosen in a preceding canonical correspondence analysis (CCA) with the forward selection procedure, and tested with the Monte Carlo test for significance at each inclusion in the model. Consequently, three variables were selected at $\mathrm{P}=0.01$ : depth, medium sand and very fine sand. They were used in the environmental matrix to perform both the two CCAs and the two partial CCAs of the species variation partitioning.

The qualitative parameter used was "season of the year", related with each sampling period (spring, summer, autumn and winter), which yielded 4 dummy binary variables (instrumental variables). The matrix constructed with the dummy variables was named "time matrix" (20 stations $x 4$ seasons).

\section{Statistical analyses}

Five ordination analyses were done: one $\mathrm{CA}$, two CCA and two partial CCA. The CANOCO Program version 3.12 (ter Braak, 1988) was employed. The first analysis (CA) provides the sum of all eigenvalues obtained for the species matrix, in order to transform the amount of variation accounted for by the explanatory variables in percentages of the total variation of the species data. The first CCA was done with the species matrix constrained by the environmental matrix (step 1). The second CCA was done with the species matrix constrained by the time matrix (step 2). The first partial CCA was performed like step 1, but removing the effect of time, that is, using time as covariable (step 3). The last partial CCA was performed like step 2, but using the environmental matrix as covariable (step 4). As proposed by Borcard's et al. (1992), to transform the measures of the amount of variation, given by the canonical eigenvalues, into percentages of the explained variation of the species data, the sum of all canonical eigenvalues was divided by the sum of all eigenvalues of the correspondence analysis of the species matrix (CA). The overall amount of explained variation of the species matrix is done either by the sum of eigenvalues obtained in step (1) plus step (4), or by the sum of eigenvalues of step (2) plus step (3). The percent of undetermined variation and stochastic fluctuations is calculated by 100 minus the overall amount of explained variation of the species matrix.

\section{Results}

A total of 11,197 organisms belonging to 93 species were obtained from the channel area. From this total, twenty-four species were the most abundant and frequent and represented nearly $89 \%$ of the total number of individuals sampled (Table 1). Echinodermata and Mollusca dominated the fauna in number of individuals, followed by Crustacea. These groups accounted for about $84 \%$ of the number of species: 40 (43\%) were Crustacea, 25 (27\%) Mollusca and 13 (14\%) Echinodermata.

The most frequent and abundant species in the catches were Encope emarginata, highly dominant at the southern station 4, Luidia senegalensis, present in $95 \%$ of the stations, Luidia clathrata (in 90\%), and Farfantepenaeus brasiliensis, Astropecten brasiliensis and Callinectes ornatus found in $85 \%$ of the stations sampled. Other abundant species in the area were the gastropod Strombus pugilis and the shrimps Litopenaeus schmitti and Xiphopenaeus kroyeri. These three species together with Encope emarginata showed a seasonal pattern of abundance: the first and the latter most numerous in summer and the others present only in autumn.

The distribution of abundance over the year showed opposite numbers in summer and winter, with intermediate values in spring and autumn (Table 1), suggesting a different structure of the assemblages in each period.

In relation to the species ecological variation partitioning, the correspondence analysis of the species matrix (CA) pointed out that the sum of all eigenvalues equals 1.448 . The percentage of the total explained variation of the species data and the sum of all canonical eigenvalues at each step of the method is presented in Table 2.

Figure 2 illustrates the relative importance of the various processes that control the variation of the benthic megafauna in the São Sebastião Channel. The total variation of the species abundance can be partitioned as follows: a) pure environmental variation: $38.7 \%$; b) pure temporal variation: $16.9 \%$; c) environmental variation with temporal influence (that is, covariation between the environmental variables and time) [(step 1 - step 3) or (step 2 - step 4)]: $0.5 \%$; d) undetermined variation and stochastic fluctuations: $43.9 \%$. The total amount of the explained variation of the species matrix is $56.1 \%$, and about one-third of this amount can be predicted by the supplied instrumental variable, season of the year. This means that the processes governing the species abundance distribution have a significant temporal structuring component, independent of the environmental variables considered. Also, the major 
part of the variation explained by the environmental variables is due to non temporal effects, since only a residual amount of the environmental variation is shared by time.

The influence of the environmental factors non temporally structured on the abundance of the species (step 3) is spatially represented in Figure 3. The species names are coded in Table 1 . The ordination diagram shows a gradient of species replacement along axis $\mathrm{I}$, from coarse to fine sandy stations. In consequence, axis I can be interpreted as the sediment pattern present at the sampled areas of the Channel, distinguishing the southern station 1, with 90 to $96 \%$ of very fine sand, from the northern station 5 , with 9 to $35 \%$ of coarse sand. On the other hand, axis II can be related to depth, grouping deeper stations subject to the influence of the open sea (station 2).

Table 1. Number of individuals of 24 most common megabenthic species in 40 seasonal catches from São Sebastião Channel. $\mathrm{He}=$ Herbivore; $\mathrm{D}=$ Detritivore $\mathrm{C}=$ Carnivore; $\mathrm{O}=$ Omnivore; $\mathrm{P}=$ Parasite.

\begin{tabular}{|c|c|c|c|c|c|c|c|c|}
\hline SPECIES & CODE & GROUP & GUILD & SPRING & SUMMER & AUTUMN & WINTER & TOTAL \\
\hline Strombus pugilis & Stpu & Mollusca & $\mathrm{He} / \mathrm{D}$ & 201 & 2817 & 12 & 87 & 3117 \\
\hline Encope enarginata & Enem & Echinodermata & $\mathrm{D}$ & 0 & 1368 & 3 & 912 & 2283 \\
\hline Callinectes ornatus & Caor & Crustacea & $\mathrm{C}$ & 111 & 125 & 531 & 107 & 874 \\
\hline Lytechimus variegatus & Lyva & Echinodermata & $\mathrm{He} / \mathrm{D}$ & 479 & 160 & 31 & 122 & 792 \\
\hline Farfantepenaeus brasiliensis & Fabr & Crustacea & $\mathrm{O}$ & 90 & 198 & 84 & 18 & 390 \\
\hline Litopenaeus schmitti & Lisc & Crustacea & $\mathrm{O}$ & 0 & 0 & 372 & 3 & 375 \\
\hline Luidia senegalensis & Luse & Echinodermata & $\mathrm{C}$ & 78 & 51 & 131 & 74 & 334 \\
\hline Luidia clathrata & Lucl & Echinodermata & $\mathrm{C}$ & 77 & 27 & 72 & 53 & 229 \\
\hline Siratus senegalensis & Sise & Mollusca & $\mathrm{C}$ & 68 & 26 & 80 & 0 & 174 \\
\hline Dardanus a. insignis & Dain & Crustacea & $\mathrm{C}$ & 47 & 11 & 77 & 33 & 168 \\
\hline Astropecten brasiliensis & Asbr & Echinodermata & $\mathrm{C}$ & 42 & 12 & 27 & 56 & 137 \\
\hline Astropecten marginatus & Asma & Echinodermata & $\mathrm{C}$ & 60 & 14 & 42 & 18 & 134 \\
\hline Hepatus pudibundus & Hepu & Crustacea & $\mathrm{C}$ & 36 & 12 & 74 & 12 & 134 \\
\hline Luidia alternata & Lual & Echinodermata & $\mathrm{C}$ & 12 & 86 & 12 & 13 & 123 \\
\hline Echinaster brasiliensis & Ecbr & Echinodermata & $\mathrm{C}$ & 18 & 33 & 21 & 24 & 96 \\
\hline Xiphopenaeus kroyeri & Xikr & Crustacea & $\mathrm{O}$ & 0 & 0 & 96 & 0 & 96 \\
\hline Paguristes erythrops & Paer & Crustacea & $\mathrm{C}$ & 23 & 20 & 0 & 38 & 81 \\
\hline Persephona punctata & Pepu & Crustacea & $\mathrm{C}$ & 5 & 2 & 21 & 45 & 73 \\
\hline Trachypenaeus constrictus & Trco & Crustacea & $\mathrm{O}$ & 17 & 17 & 21 & 12 & 67 \\
\hline Cymathium parthenopeum & Cypa & Mollusca & $\mathrm{C}$ & 12 & 18 & 15 & 11 & 56 \\
\hline Persephona lichstensteinii & Peli & Crustacea & $\mathrm{C}$ & 0 & 0 & 41 & 14 & 55 \\
\hline Ophioderma januarii & Opja & Echinodermata & $\mathrm{D}$ & 0 & 30 & 6 & 18 & 54 \\
\hline Pleoticus mulleri & Plmu & Crustacea & $\mathrm{O}$ & 23 & 0 & 20 & 11 & 54 \\
\hline Cymothoa excisa & Cyex & Crustacea & $\mathrm{P}$ & 6 & 42 & 2 & 2 & 52 \\
\hline \multicolumn{4}{|c|}{ Number of individuals of the top 24 species } & 1405 & 5069 & 1791 & 1683 & 9948 \\
\hline \multicolumn{4}{|c|}{ Number of individuals of all species } & 1578 & 5673 & 2103 & 1843 & 11197 \\
\hline
\end{tabular}


Table 2. Results of the Canonical Correspondence Analysis for megabenthos from the São Sebastião Channel, in each one of the four steps of the ecological variation partitioning.

\begin{tabular}{cccc}
\hline ANALYSIS & MATRICES & $\begin{array}{c}\text { SUM OF ALL } \\
\text { CANONICAL } \\
\text { EIGENVALUES }\end{array}$ & $\begin{array}{c}\text { EXPLAINED } \\
\text { VARIATION } \\
(\%)\end{array}$ \\
\hline CCA & $\begin{array}{c}\text { Species matrix } \\
\text { constrianed by } \\
\text { environmental } \\
\text { matrix }\end{array}$ & 0.567 & 39.2 \\
CCA & $\begin{array}{c}\text { Species matrix } \\
\text { constrained by } \\
\text { time matrix } \\
\text { (Step 2) }\end{array}$ & 0.252 & 17.4 \\
CCA & $\begin{array}{l}\text { Species matrix } \\
\text { constrained by } \\
\text { (Step 3) } \\
\text { environmental } \\
\text { matrix } \\
\text { Covariable: } \\
\text { time matrix } \\
\text { Species matrix } \\
\text { constrained by } \\
\text { time matrix } \\
\text { Covariable: } \\
\text { environmental } \\
\text { matrix }\end{array}$ & 0.560 & 38.7 \\
(Step 4) & 0.245 & \\
& & \\
\hline
\end{tabular}

Overall amount of explained variation of the species matrix $=$ $56.1 \%$

(steps 1 +4) or (steps $2+3$ )
The variation of the species abundance data left after removing the effect of the environmental factors (step 4) is shown in Figure 4. The ordination diagram shows the temporal species distribution in the Channel. The positive side of axis I distinguishes those species present exclusively or predominantly in autumn from the others present in the rest of the seasons. Species highly correlated to this axis are Xiphopenaeus kroyeri and Litopenaeus schmitti which are present in the area only in autumn. In the negative side of axis I are placed species particularly numerous in summer, as Strombus pugilis and Encope emarginata. A central group around the intersection of both axes was identified with species of wide temporal distribution, present all the year round, and showing no relation to the canonical axes formed.

The importance of each environmental factor and each temporal factor on the species abundance data is indicated through the correlation coefficients of the variables with axes (Table 3). The species are highly correlated with sedimentological parameters in axis 1 and with depth in axis 2 (Fig. 3), and with autumn in axis 1 and spring in axis 2 (Fig. 4).

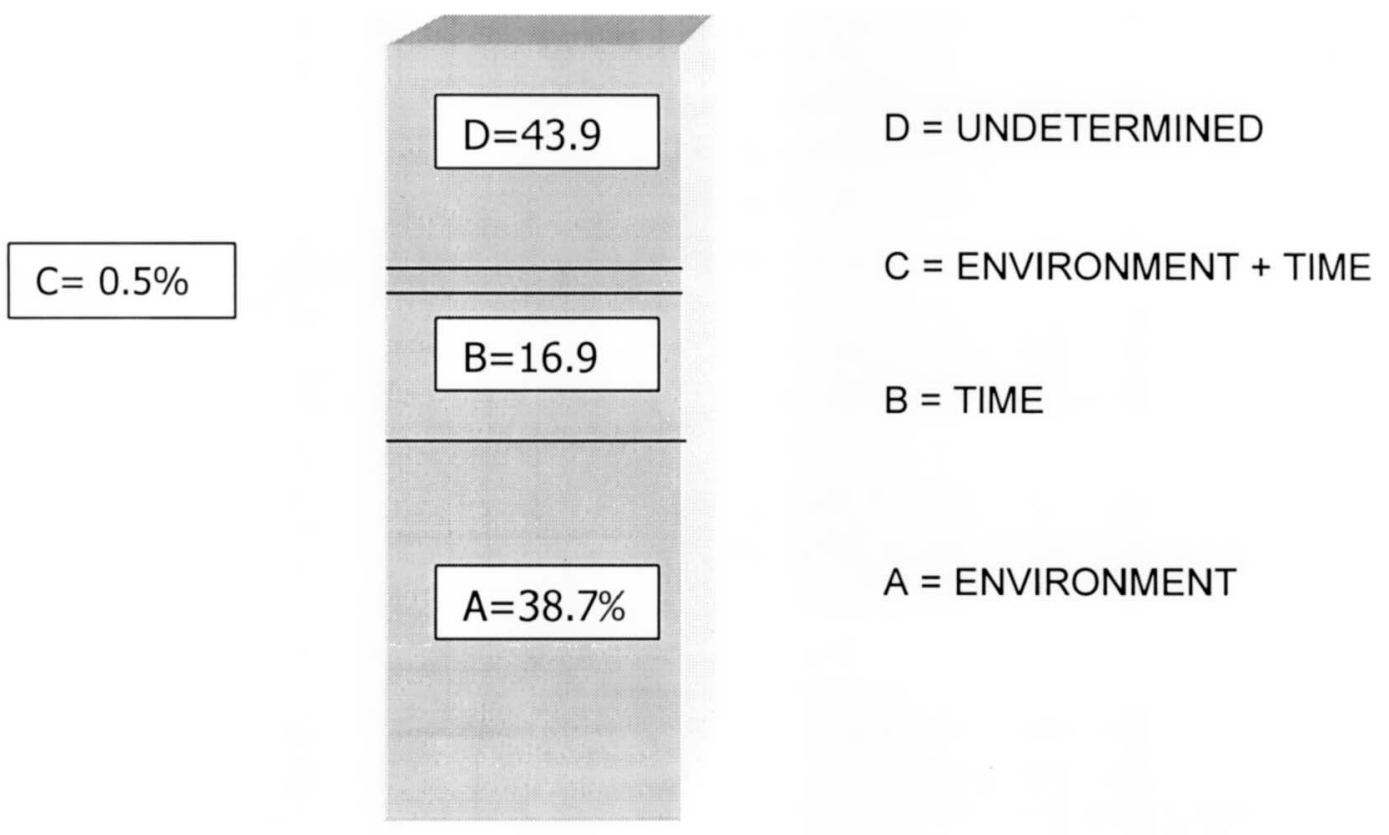

Fig. 2. Diagram showing the explained ecological variation partition for the megabenthic species in the São Sebastião Channel. 


\section{E I I (13.9\%)}

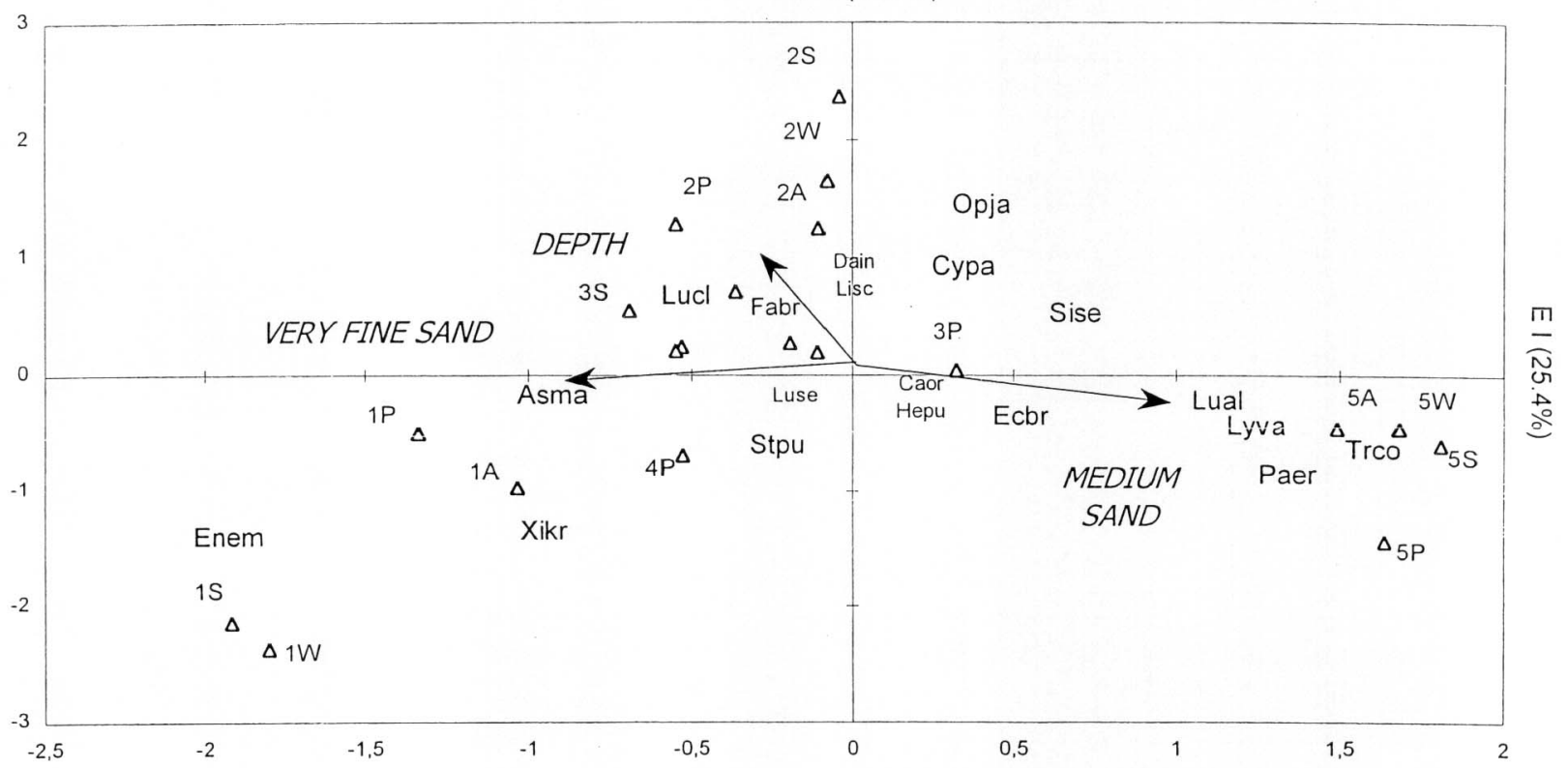

Fig. 3. Partial canonical correspondence analysis showing the effect of the environmental variables without temporal influence on the species distribution. Species names coded in Table 1. Stations coordinates are indicated in open triangles. $\mathrm{P}=$ Spring; $\mathrm{S}=$ Summer; $\mathrm{A}=$ Autumn; $\mathrm{W}=\mathrm{W}$ inter. Arrows show magnitude and direction of environmental variables.

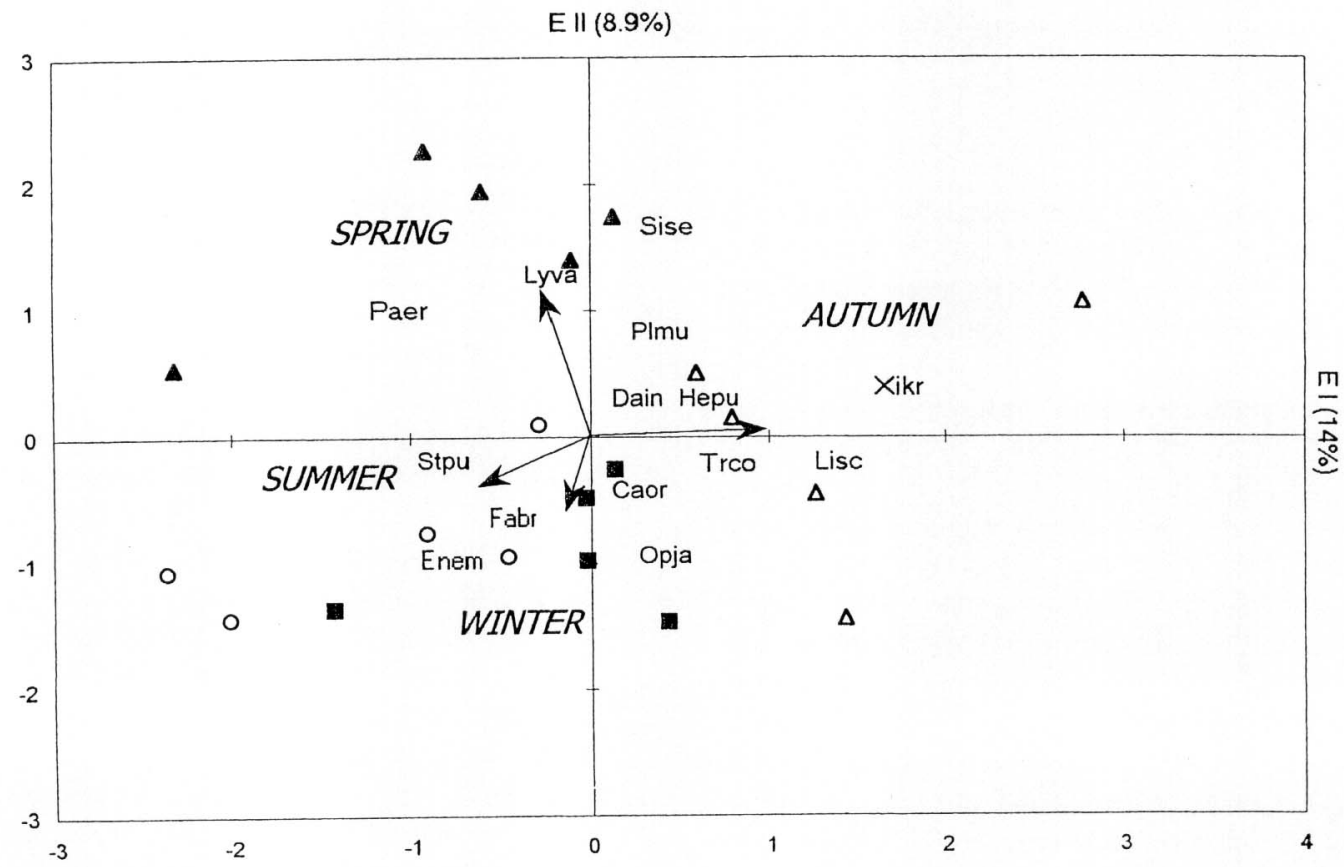

Fig. 4. Partial canonical correspondence analysis showing the effect of time on the species distribution, after removing the effect of environmental factors. Species names coded in Table 1. Black triangles = spring stations; White circles = summer stations; white triangles = autumn stations; black quadrats = winter stations. Arrows show magnitude and direction of temporal variables. 
Table 3. Summary statistics for the two models obtained with patial Canonical Correspondence Analysis for megabenthos from São Sebastião Channel, considering "Time" as covariable (model A) and "environmental factors" as covariable (model B). Significative values of correlation in bold.
A. INFLUENCE OF ENVIRONMENTAL
B. INFLUENCE OF TIME ONLY FACTORS ONLY

\begin{tabular}{|c|c|c|c|c|c|}
\hline AXES & I & II & AXES & I & II \\
\hline Eigenvalues & 0.303 & 0.167 & Eigenvalues & 0.104 & 0.073 \\
\hline $\begin{array}{l}\text { Species-environment } \\
\text { correlations }\end{array}$ & 0.925 & 0.878 & $\begin{array}{l}\text { Species-environment } \\
\text { correlations }\end{array}$ & 0.871 & 0.846 \\
\hline $\begin{array}{l}\text { Percentage of variance of } \\
\text { species data of } \\
\text { species-environment } \\
\text { relation }\end{array}$ & $\begin{array}{l}25.4 \\
54.2\end{array}$ & 13.9 & $\begin{array}{l}\text { Percentage of variance } \\
\text { of species data } \\
\text { of species-environment } \\
\text { relation }\end{array}$ & 14.0 & 9.8 \\
\hline \multicolumn{3}{|c|}{$\begin{array}{c}\text { CORRELATION OF ENVIRONMENTAL } \\
\text { DATA }\end{array}$} & \multicolumn{3}{|c|}{$\begin{array}{c}\text { CORRELATION OF TEMPORAL } \\
\text { DATA }\end{array}$} \\
\hline Depth & -0.176 & 0.730 & Spring & -0.529 & 0.651 \\
\hline Very Fine Sand & -0.754 & -0.130 & Summer & -0.388 & -0.460 \\
\hline \multirow[t]{2}{*}{ Medium Sand } & 0.840 & -0.266 & Autumn & 0.793 & 0.242 \\
\hline & & & Winter & 0.074 & -0.468 \\
\hline
\end{tabular}

\section{Discussion}

The results show that a large part of the total variation present within the data can be attributed to environmental factors $(38.7 \%)$, mainly to sand size and depth, as indicated by the correlation analysis. Indeed, shallow coarse sandy places could be separated from deeper finer bottoms, showing the importance of those variables in discriminating different habitats in the Channel. Previous work carried out in the area (Pires-Vanin, unpublished) recognized four sub-areas based on the species abundance data: three location groups were formed taking into account the grain size distribution over the bottom, and one group was found encompassing species from deeper places.

After excluding the effect of environmental variables, a significant temporal structure remained on the species abundance variation (16.9\%). This quantity is the amount of variation exclusively affected by processes under temporal control. Actually, physical and biological processes of such kind have been identified by several authors for the southeastern Brazilian shelf ecosystem (Castro Filho et al., 1987; Moser \& Gianesella-Galvão, 1997; Ventura et al., 1997; Santos \& Pires-Vanin, 1999).
The seasonally controlled oceanographic process in the study area is the intrusion of the South Atlantic Central Water (SACW) from the slope towards the coast. The process starts in springtime and reaches its maximum in summer. The SACW causes a severe change in the communities structure (Pires, 1992; Matsuura, 1998), which most probably is responsible for the main fraction of temporal variance identified on the dataset. During the sampled period in February 1994 cold water was present at 40 $m$ depth but just a few days before it stayed in shallower places along the island side (Leandro, 1999). Therefore, we can assume that the contribution of temporal components to variation can be somewhat underestimated in our result. When SACW retreats, in autumn, the Coastal Water (CW) fills the coastal area and consequently the water column becomes uniformly warm. At this time the entrance of shrimps species occurs, changing the community structure (Pires-Vanin et al., 1997). As the present results point out, autumn and spring samples are very different in structure.

Another structuring factor with temporal control is linked to the biological cycles of some megabenthic key-species. We observed an intense migration of the blue crab Callinectes ornatus 
towards the inside of the Channel during summer, and also a remarkable variation in behavior of the gastropod Strombus pugilis. The latter was found in large numbers on the sediment surface during spring and summer (nearly 1450 individuals by catch) and deeply buried in autumn and winter.

There are several processes at work in the São Sebastião Channel that varies with the descriptor "time". On one hand, hydrological processes induce cyclic variations in the system, and "time" is used as a proxy for variables like temperature, oxygen content, and so on, and these variables can theoretically be measured as ordinary environmental descriptors. On the other hand, community variation also occurs as a result of species-level processes such as migrations and life-cycles, which may be influenced by time also. These processes are much more difficult to quantify directly. In interpreting the results we considered "time" closely related to "seasonal variation". It is dependent on temperature, which influences directly the presence and abundance of the species, and on water masses, which is also temperature related. So, when referring to "time" we consider an interaction of physical and biological processes, expressed through the effect of the water masses in bringing new predators and food for benthic species, causing migrations and influencing reproduction.

More than $95 \%$ of the variation explained by the temporal matrix is independent of the environmental descriptors considered. Indeed, the significant environmental descriptors in the São Sebastião Channel were sand grain size and depth, both of them relatively independent of season or time. In its turn, the quantity of unexplained variation is not so high $(43.9 \%)$ considering that the ordination techniques reduce dimensions, and as a result there is always a loss in variation. According to Borcard et al. (1992), it varied widely among different communities: from 35 to $68 \%$ for bacteria, forest and lake community data. The São Sebastião Channel is oceanographically a very complex area, with the hydrodynamics highly influenced by predominant winds and controlled by water masses (Fontes, 1995; Silva, 1995; Coelho, 1997) and added by a patchy sedimentation of the seafloor (Furtado, 1995). So, many biological and physical variables interact to structure the communities contributing to the unexplained fluctuations.

The influence of all factors regulating the relationship diversity-species abundance is difficult to measure. Many biological interactions should be evaluated only throughout particular experimental designs. Nevertheless, the present results demonstrate that the dynamics of the megafauna from the São Sehastião Channel is affected mainly by the environment, with an important temporal component in the species distribution which is quantitatively shown here for the first time.

\section{Acknowledgments}

The author is grateful to Fundação de Amparo à Pesquisa do Estado de São Paulo (FAPESP) for the financial support to the research project Oceanografia da Plataforma Interna de São Sebastião (OPISS) (FAPESP $n{ }^{\circ}$ 92/3449-0). The paper benefited from the reviewers comments.

\section{References}

Aidar, E.; Gaeta, S. A.; Gianesella-Galvão, S. M. F.; Kutner, M. B. B. \& Teixeira, C. 1993. Ecossistema costeiro tropical: nutrientes dissolvidos, fitoplâncton e clorofila- $a$, e suas relações com as condições oceanográficas na região de Ubatuba. Publção esp. inst. oceanogr., (10):9-43.

Borcard, D.; Legendre, P. \& Drapeau, P. 1992. Partialling out the spatial component of ecological variation. Ecology, 73(3): 1045-1055.

Cassie, R. M. \& Michael, A. D. 1968. Fauna and sediments of an intertidal mud flat: a multivariate analysis. J. expl. mar. Biol. Ecol., 2:1-23.

Castro Filho, B. M.; Miranda, L. B. \& Miyao, S. Y. 1987. Condições hidrográficas na plataforma continental ao largo de Ubatuba; variações sazonais e em média escala. Bolm Inst. oceanogr., S Paulo, 35(2):135-151.

Coelho, A. L. 1997. Massas de água e circulação no Canal de São Sebastião (SP). M.Sc. Thesis. University of São Paulo, Oceanographic Institute. 244p.

Fontes, R. F. C. 1995. As correntes do Canal de São Sebastião, São Paulo. M.Sc. Thesis. University of São Paulo, Oceanographic Institute. 159p.

Furtado, V. V. 1995. Sedimentação quaternária no Canal de São Sebastião. Publção esp. Inst. oceanogr., (11):27-35.

Gaudette, H. E.; Flight, W. R.; Towner, L. \& Folger, D. W. 1974. An inexpensive tritation method for the determination of organic carbon in recent sediments. J. sedim. Petrology, 44(1):249-253.

Gross, M. G. 1971. Analysis of carbonaceous organic matter in sediments and sedimentary rocks. In: Carver, R. E ed. Procedures in sedimentary petrology. New York, WileyInterscience. p. 573-596. 
Jackson, J. B. C. 1972. The ecology the molluscs of Thalassia communities, Jamaica, West Indies. II Molluscan population variability along an environmental stress gradient. Mar. Biol., 14 (4):304-337.

Leandro, R. P. 1999. Climatologia das águas do Canal de São Sebastião (SP). M.Sc. Thesis. University of São Paulo, Oceanographic Institute. 162p.

Long, B. G.; Poiner, I. R. \& Wassenberg, T. J. 1995. Distribution, biomass and community structure of megabenthos of the Gulf of Carpentaria, Australia. Mar. Ecol. Prog. Ser., 129(1-3):127139.

Maes, J.; Taillieu, A.; van Damme, P. A.; Cottenie, K. \& Ollevier, F. 1998. Seasonal patterns in the fish and crustacean community of a turbid temperate estuary (Zeeschele Estuary, Belgium). Estuar. coast. Shelf Sci., 47(2):143-151.

Matsuura, Y. 1998. Brazilian sardine (Sardinella brasiliensis) spawning in the southeast Brazilian Bight over the period 1976-1993. Rev. bras. oceanogr., 46(1):33-43.

Moser, G. A. O. \& Gianesella-Galvão, S. M. F. 1997. Biological and oceanographic upwelling indicators at Cabo Frio (RJ). Rev. bras. oceanogr., 45(1-2): 11-23.

Pérez-Farfante, I. \& Kensley, B. 1997. Penaeoid and Sergestoid shrimps and prawns of the world. Mém Mus Nat Hist Nat, Zool., 175:1-233.

Pires, A. M. S. 1992. Structure and dynamics of the benthic megafauna from the continental shelf offshore of Ubatuba, southeastern Brazil. Mar. Ecol. Prog. Ser., 86(1):63-76.

Pires-Vanin, A. M. S. 1993. A macrofauna bêntica da plataforma continental ao largo de Ubatuba, São Paulo, Brasil. Publção esp. Inst. oceanogr., (10): 137-158.

Pires-Vanin, A. M. S.; Corbisier, T. N.; Arasaki, E. \& Moellmann, A. M. 1997. Composição e distribuição espaço-temporal da fauna bêntica no Canal de São Sebastião. Rel. Téc. Inst. oceanogr., S Paulo, (41):29-46.

Riley, J. P. 1971. The dissolved gases in the sea water. I gases other than Carbon Dioxide. In: Riley, J. P. \& Chester, R. eds Introduction to marine chemistry. London, Academic Press, p. 105-120.
Santos, M. F. L. \& Pires-Vanin, A. M. S. 1999. The Cumacea community of the southeastern Brazilian continental shelf: structure and dynamics. Sci. Mar., 63(1):15-25.

Silva, L. S. 1995. Condições oceanográficas no Canal de São Sebastião e na região costeira adjacente: variações sazonais entre fevereiro de 1994 e março de 1995. M.Sc. Thesis. University of São Paulo, Oceanographic Institute. 128p.

Soto, L. A.; Manickhand-Heileman, S.; Flore, E. \& Licea, S. 1999. Processes that promote decapod diversity and abundance on the upper continental slope of the southwestern Gulf of Mexico. In: INTERNATIONAL CRUSTACEAN CONGRESS, 4. The biodiversity crisis and crustacea. Rotterdam, 1999. Proceedings. Rotterdam, Balkema. p. 395-400.

Suguio, K. 1973. Introdução à sedimentologia. São Paulo, Edgar Blucher/EDUSP. 317p.

Sumida, P. Y. \& Pires-Vanin, A. M. S. 1997. Benthic Associations of the shelfbreak and upper slope off Ubatuba-SP, South-eastern Brazil. Estuar. coast. Shelf Sci., 44(6):779-784.

ter Braak, C. J. F. 1988. Partial canonical correspondence analysis. In: Bock, H. H. ed. Classification and related methods of data analysis. Amsterdam, Elsevier, p.551-558.

UNESCO. 1973. International oceanographic tables, v. 2 .

Valério-Berardo, M. T.; Flynn, M. N. \& Wakabara, Y. 2000. Structure and dynamics of a shelf amphipod taxocenosis in southeastern Brazil. Bull. mar. Sci., 66(1):59-72.

Ventura, C. R. R.; Falcão, A. P. C.; Santos, J. S. \& Fiore, C. S. 1997. Reproductive cycle and feeding periodicity in the starfish Astropecten brasiliensis in the Cabo Frio upwelling ecosystem (Brazil). Inv. Repr. Develop., 31:1-3.

(Manuscript received 24 May 2001; revised 08 August 2001; accepted 17 December 2001) 